\title{
Other Generations' Interpretation and Use of the Past: the Case of the Picture Stones on Gotland
}

\author{
Mats Burström
}

\begin{abstract}
Throughout history, ancient monuments and artefacts have been ascribed many meanings in a multitude of contexts. What consequences does this have for archaeological interpretation and for archaeology as a discipline? The discussion focuses on one single category of ancient monuments: the Gotlandic picture stones, originally raised during the period A.D. $400-1100$.
\end{abstract}

Mats Burström, Department of Archaeology, Stockholm University, S-10691 Stockholm, Sweden.

The meaning of ancient monuments and artefacts is not restricted to the time when they came into being. On the contrary, they have repeatedly attracted attention and been ascribed meaning throughout history. This applies in particular to those monuments that are well visible in the landscape. For centuries, and in many cases for thousands of years, these have been interpreted and made meaningful elements in the landscape.

The generations that have followed after the monuments came into being have interpreted and used the monuments in their own way. As time passed the monuments were ascribed a multitude of meanings. An obvious example of how a monument is ascribed meaning throughout history is, of course, Stonehenge. As Christopher Chippindale has shown, this monument has been interpreted and used in every imaginable way and then some during its history (Chippindale 1983).

Not even at the time when the monuments were built, however, did they have one, singular meaning. Different persons had different opinions about their meaning. The monument that for someone was a memorial over a beloved one, was for another a remin- der of a hated tyrant, and for yet another it was foremost a landmark by which to orientate oneself in the landscape. The meaning of a monument exceeded the originators' intention already from the beginning. This process has continued ever since in what Richard Bradley has called "the afterlife of monuments" (Bradley 1993).

If we want a more profound understanding of the meanings of ancient monuments we cannot restrict our study to the supposed intention behind their making. Instead, we have to adopt a long-term perspective and consider the multiplicity of meanings that the monuments have been ascribed (Burström 1993). It is first when we consider also other generations' interpretation and use of the monuments that we fully realize the extent of their meaning.

\section{PICTURE STONES AND RESEARCH TRADITIONS}

In the following, interest will focus on meanings that have been ascribed to a single category of ancient monuments: the Gotlandic picture stones. As a background to the discussion it may be helpful to give a short presentation of these stones and research 


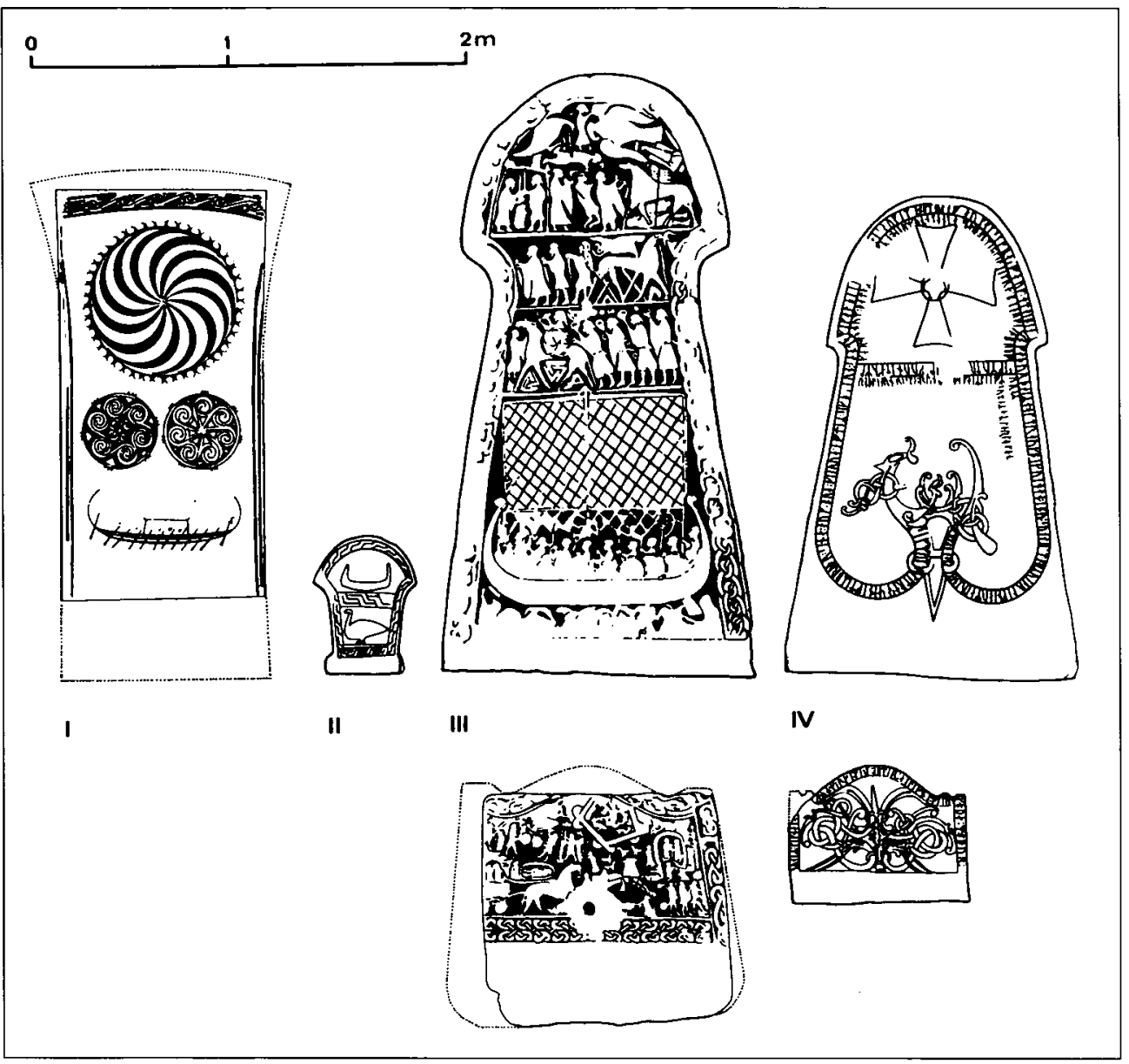

Fig. 1. The four, chronologically separated, main groups of Gotlandic picture stones. After Andrén 1993:35.

traditions.

Today we know of about 440 Gotlandic picture stones. Of these, only four have been discovered outside Gotland. Two stones have been found in Öland, one in Uppland, and one in Latvia (cf. Key Map, p. 223). The picture stones were made during a period of approximately seven hundred years, from $\mathrm{c}$. A.D. 400 till 1100.

The Gotlandic picture stones can be divided into four, chronologically separated, main groups (cf. Andrén 1993:35-36; Nylén \& Lamm 1988:171-172; Lindqvist 1941-
1942), fig. 1.

The first group of stones is dated to c. $400-$ 600 . It consists of tall stone slabs which were raised as gravestones. The pictures are mainly abstract, such as circles and spirals. On the lower part of the stone there is often a ship.

The second group of stones is dated to $\mathrm{c}$. 600-800. It consists of small stones ("dwarf stones") which were probably raised as gravestones. The pictures are mainly stylized ships, birds and animals with antlers.

The third group of stones is dated to $c$. 800-1000. Two different types of stones 


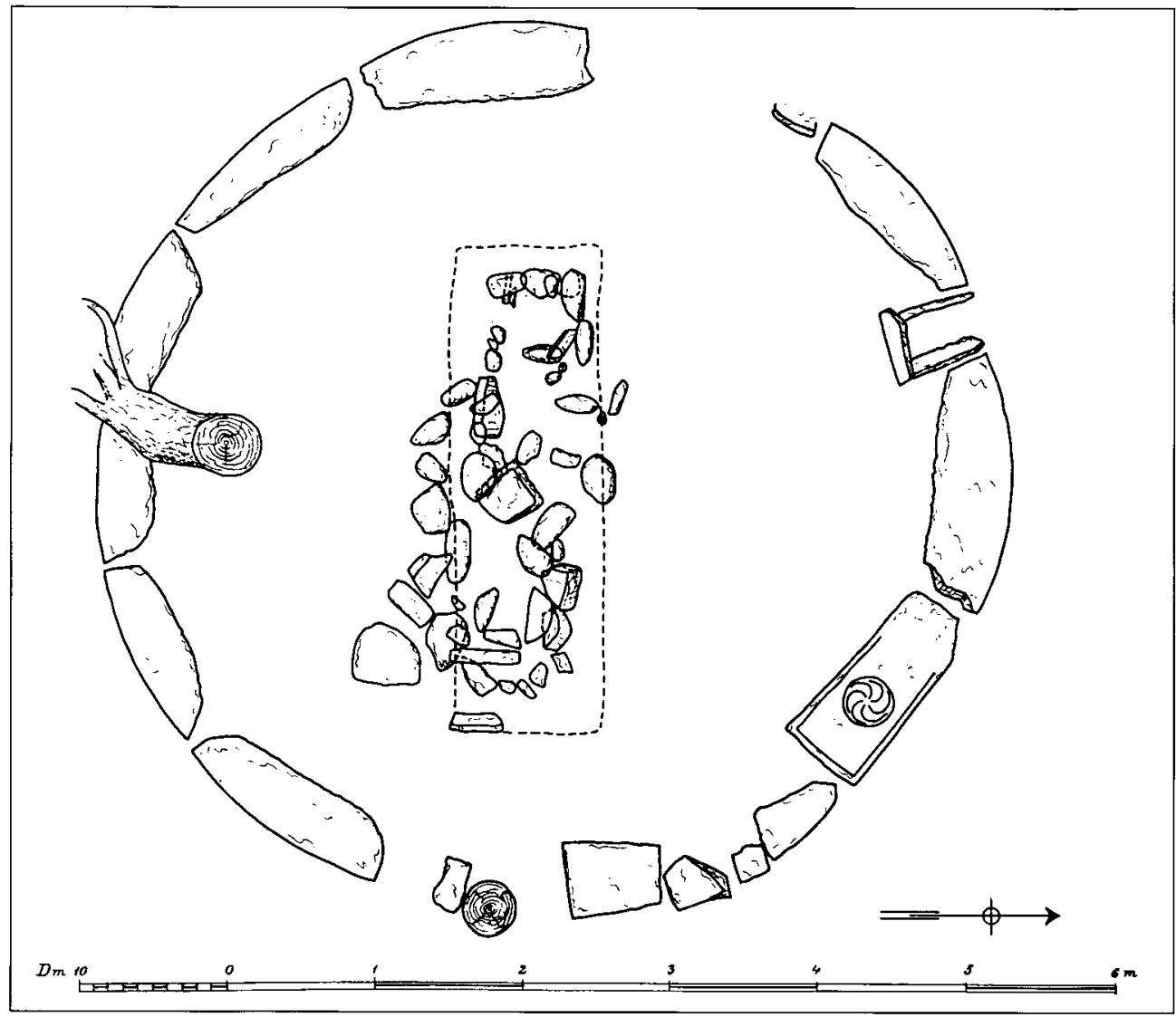

Fig. 2. A Gotlandic picture stone of the oldest type was found in the stone kerb of a late Viking Age grave at the Ihre-cemetery. After Stenberger 1962:8.

occur: most are large slabs with a keyhole shape, but there are also a few smaller stones which probably formed the walls of small coffins. Both types of stones were raised as memorials, without any direct connection with graves. The stones are covered with a large number of realistic figures. Most common are sailing-ships, armed horsemen, and women with drinking horns. Many of the figures form scenes. Some of the stones also contain short runic inscriptions.

The last group of stones is dated to $c$. 1000-1100. The stones occur in the same two shapes as the stones in the third group. Also these stones were memorials without any di- rect connection with graves. This group of stones contains very few pictures. Instead they are covered with ornamental bands containing long runic inscriptions, often with Christian prayers.

The academic research traditions concerning picture stones are in themselves, of course, examples of other generations ' interpretation and use of the past. Ever since the first paper on Gotlandic picture stones was published in 1845 (Säve 1845), the stones have attracted considerable interest.

Not surprisingly, most attention has been given to the pictures on the stones. Many stones are, however, blind, that is, the pic- 


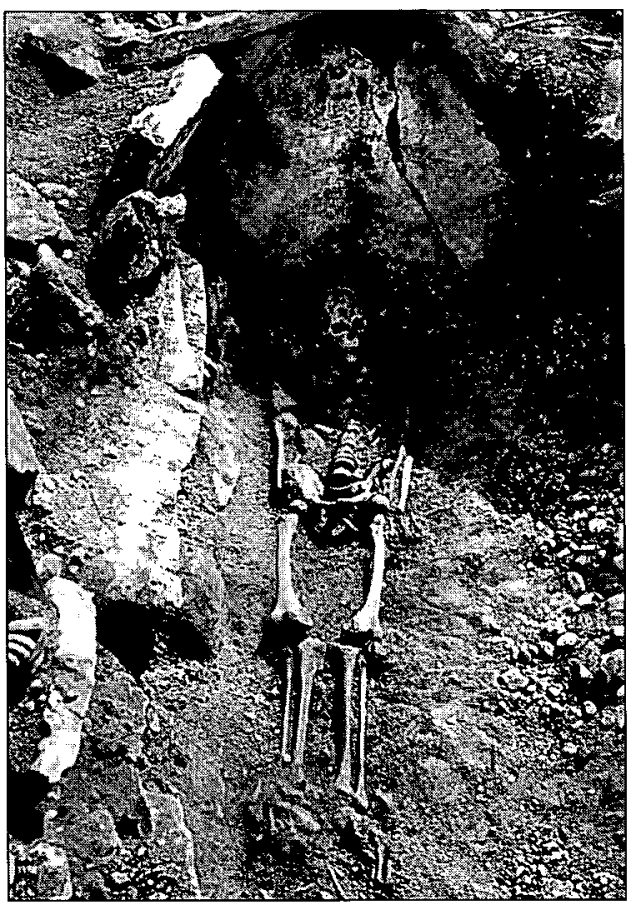

Fig. 3. In a tenth-century grave at the Ihrecemetery a picture stone had been placed upright in the head end. Photo: ATA.

tures have disappeared due to erosion caused by weather. The research has therefore been focused on a smaller number of stones, the stones with well-preserved pictures.

The research has in particular been directed towards the Viking Age stones with plenty of figures (group III above). These stones have on the one hand been interpreted as realistic pictures of everyday life, and on the other as illustrations of mythological stories and epic poems.

In the realistic tradition of interpretation the picture stones have been used as a basis for reconstructions of, for example, clothing, weapons, implements and ships. Within ship archaeology the sailing-ship figures on the picture stones have become central. The reason for this is that they show sails and riggings which are not preserved in the finds of
Viking ships (Nylén \& Lamm 1988:162-169; Lindow 1993; cf. Varenius 1992:52-54).

In the mythological tradition of interpretation the picture stones have been looked upon as illustrations of mythological stories and epic poems which are known from the Old Norse sagas. The stones have even been compared to cartoon strips (e.g. Nylén \& Lamm 1988:16). A lot of work has been invested in trying to relate the pictures to specific characters and stories in the sagas. One figure that is supposed to have been identified with certainty is, for example, Odin's eight-legged steed, Sleipnir (cf. fig. 14 , right).

The research traditions concerning picture stones closely follow the history of archaeological ideas in general. Therefore, I will not enter more deeply into a discussion of previous research. I think it is sufficient to assert that every generation of archaeologists has obviously put the questions of its own time to the ancient picture stones, and consequently the picture stones have been incorporated into different archaeological contexts.

Some picture stones were ancient already during the Viking Age. Some of them were also incorporated into new, Viking Age contexts and ascribed new meanings.

\section{VIKING AGE RE-USE}

A considerable number of picture stones have been discovered when excavating later prehistoric graves (cf. Nylén \& Lamm 1988: 13; Måhl 1990). This applies in particular to Viking Age graves. A vitally important question is whether the picture stones were used merely as building material in the graves, or were placed there because of some special meaning ascribed by the grave builders. Probably both alternatives can be correct.

In a late Viking Age grave at the Ihrecemetery in Hellvi parish a picture stone of the oldest type was found in the stone kerb, fig. 2. The picture stone is about five hundred years older than the grave. The rest of the 
stone kerb consists of carved slabs of limestone (Stenberger 1962:8-11, 131). In this case it is possible that the ancient picture stone was used by the Viking Age grave builders because of its suitable size and form.

In other cases, however, the placing of the picture stones in the graves clearly indicates that they have been ascribed special meaning. This is, for example, the case with some other Viking Age graves from the Ihre-cemetery. In a male grave from the tenth century a picture stone had been placed upright in the head end, fig. 3. The stone has no visible figures (Stenberger 1962:127). In another grave, a male grave from the eleventh century, picture stones had been placed upright in both the head end and the foot end. Both stones have well-preserved pictures, fig. 4 , which were facing towards the interior of the grave. The motif on the picture stone (Lamm 143) from the head end has been suggested to depict the resurrection of Christ (Lindqvist 1945:117-118). The two men on the sides are presumed to hold the halves of the coffin from which Christ has just been set free. This interpretation of the motif gives, of course, the placing of the picture stone in the grave a special significance.

The age of the picture stones when they were re-used in graves varies. The placing of the picture stones within the graves, however, clearly indicates that the grave builders ascribed the picture stones special meaning.

This impression is strengthened by a female grave from the second half of the tenth century at Mölner in Väte parish, fig. 5. In this grave a picture stone (Lamm 341) had been placed as a covering slab on a stone coffin. The picture stone had the pictorial side facing down towards the grave. The stone shows a sailing-ship and a woman with a drinking horn. The picture stone is probably one hundred to two hundred years older than the grave (Althin 1967; cf. Nylén \& Lamm 1988:140-141).

The repeated re-use of picture stones in graves demonstrates a Viking Age interest in

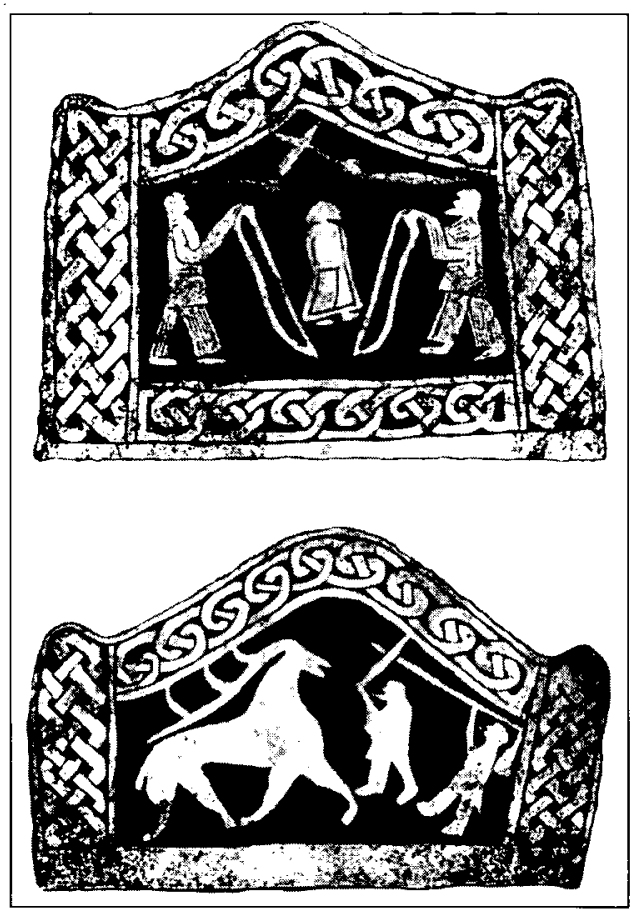

Fig. 4. Picture stones found standing upright in the head end and the foot end of an eleventhcentury grave at the Ihre-cemetery. After Nylen \& Lamm 1988:97. The motif on the upper stone has been suggested to depict the resurrection of Christ (Lindqvist 1945:117-118).

the past. This interest is known also in the form of burials in stone coffins that are five hundred years old, and in the deposition of silver hoards in house foundations of the same age. How shall we understand this $\mathrm{Vi}$ king Age interest in the past? It is probably connected with the quite radical changes that took place in society during this period. In this process the past can have been used to give historical legitimacy to contemporary ideas and claims. The picture stones can, for example, have been important in an argumentation on the theme pagan - Christian.

Fragments of a picture stone that has clearly been converted from a pagan to a Christian monument have been found in the 
ruins of St. Hans' church in Visby. The stone had been used during the thirteenth century as side slabs in a stone coffin under the church floor, fig. 6, left. The ornamentation and runic inscription show that the stone, in the middle of the eleventh century, was used as a covering slab over a late Viking Age grave, fig. 6, middle. The inscription states, "As long as the world exists may this memorial lie here above the man for whom his heirs made it..." (Nylén \& Lamm 1988:161).

A closer examination of the ornaments, however, revealed that the stone has marks of an older ornamentation. The stone turned out to be a picture stone from the oldest picture stone period, that is, from the fifth till the sixth century, fig. 6 , right.

We can thus sketch the history of this stone. It had been taken from a pagan cemetery and during the late Viking Age it was reshaped and provided with new ornamentation and a runic inscription. In that form it was laid as a grave slab next to the early Christian church. There it was not allowed

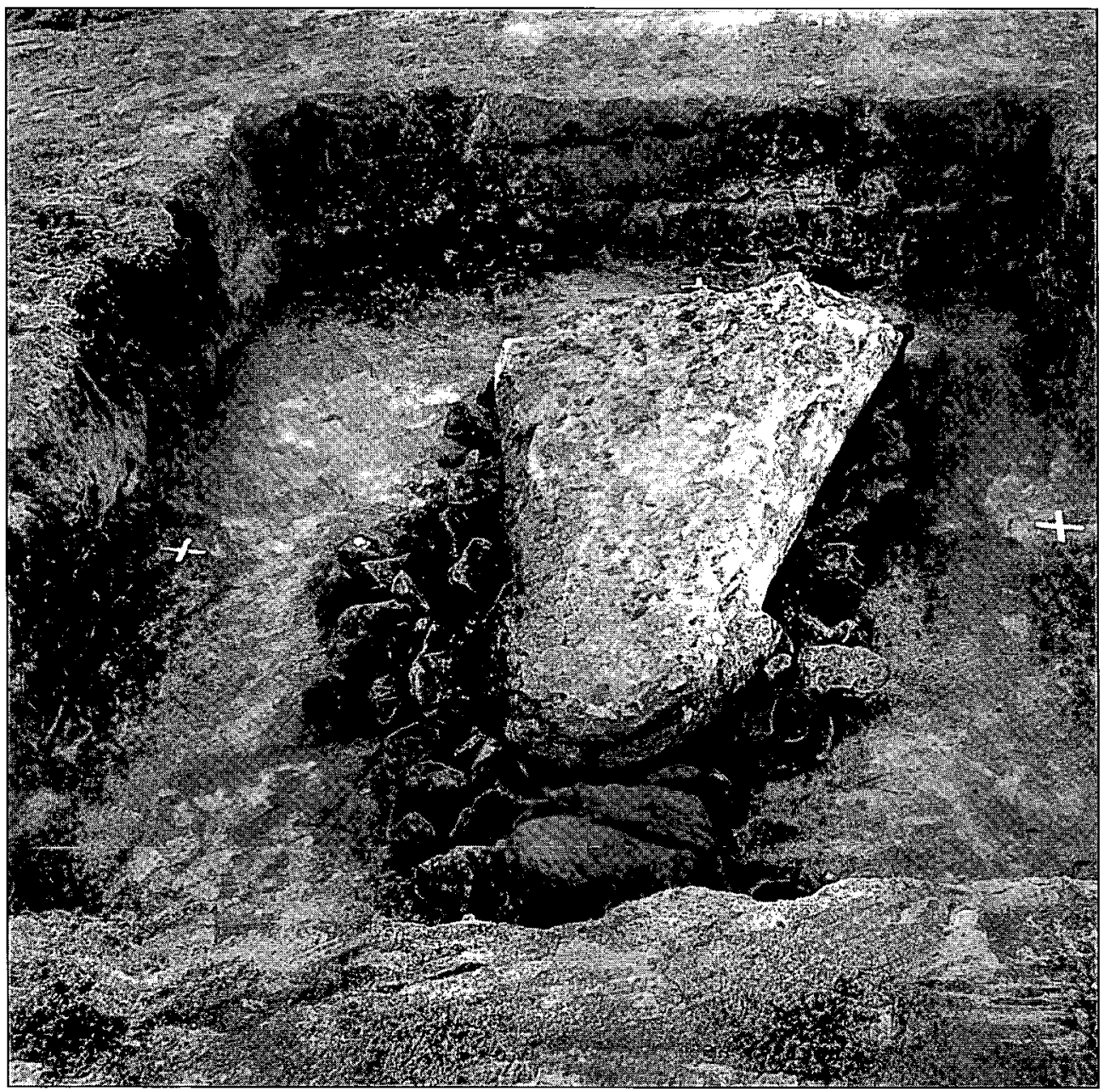

Fig. 5. A picture stone was found re-used as a covering slab on a stone coffin from the second half of the tenth century at Mölner in Väte parish. Photo: Gotland's Historical Museum. 
to "lie as long as the world exists"; instead it was cut up and probably walled in the church building. The stone was later removed in connection with a rebuilding during the thirteenth century and re-used again, this time as side slabs in a stone coffin under the church floor (Swanström 1983; cf. Nylén \& Lamm 1988:160-161). This picture stone has moved, in time and space as well as in ornamentation, from a pagan to a Christian world. As we will see, this kind of transformation concerns a large number of picture stones.

\section{PAGAN STONES AND CHRISTIAN CHURCHES}

Approximately half the number of picture stones with known find-spots (c. 192 of 404) have been found in medieval churches and churchyards (cf. Lamm 1988). Most of these picture stones have been walled in the church building. The greatest number of picture stones has been found in Stenkyrka church where some fifty stones and fragments of stones have been recovered. The parish name - Stenkyrka - literally means "stone church."

The medieval church builders must have carried out an extensive collection drive for picture stones at cemeteries and other places in the landscape where the stones were raised. How shall this use of picture stones be understood? We must once again ask whether the picture stones have merely been regarded as suitable building material, or have been selected because their use was ascribed special meaning. The fact that picture stones to a certain extent have also been

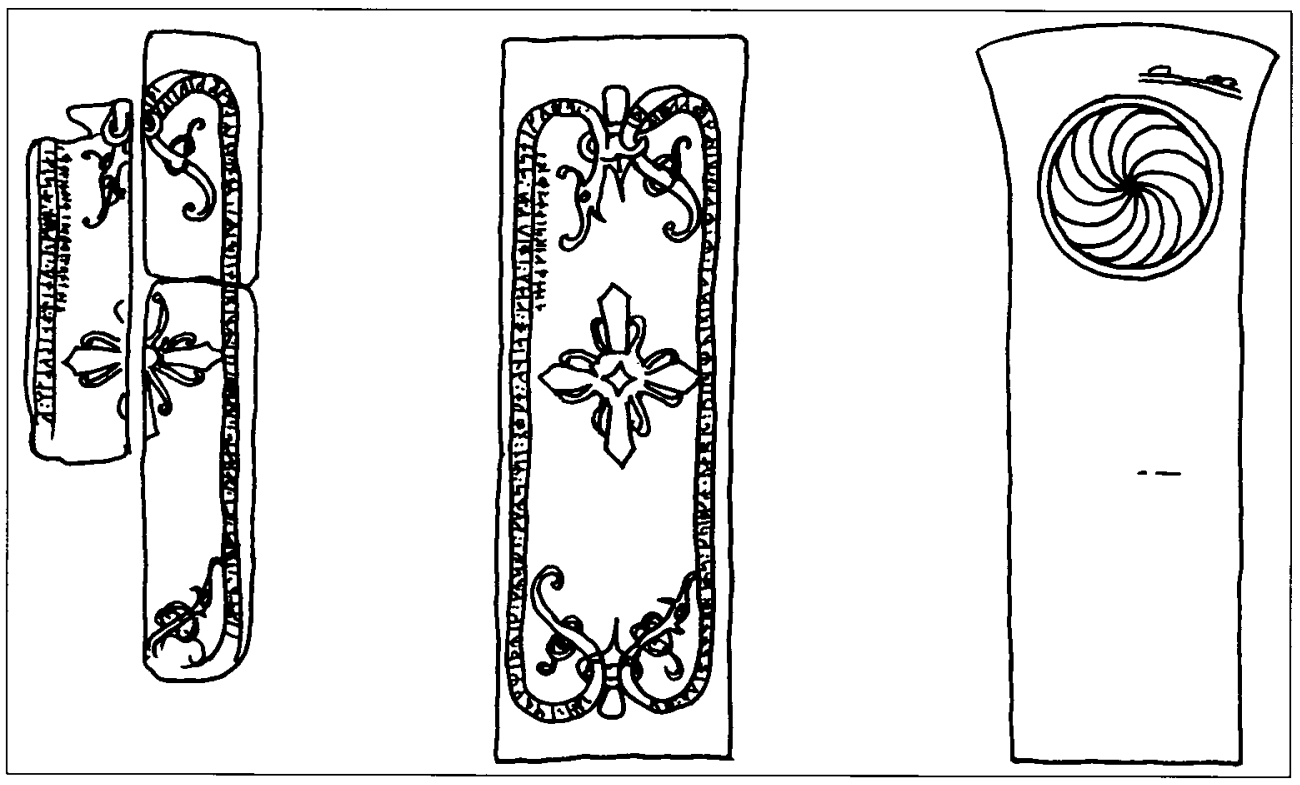

Fig. 6. The picture stone found in the ruins of St. Hans' church in Visby has moved, in time and space as well as in omamentation, from a pagan to a Christian world. Drawing after Nylén \& Lamm 1988:160.

(left) During the thirteenth century the stone was fragmented and used as side slabs in a stone coffin under the church floor. (middle) During the middle of the eleventh century the stone was removed from a pagan cemetery, reomamented, reshaped, and used as a covering slab over a late Viking Age grave. (right) During the fifth till the sixth century the picture stone was raised at a pagan cemetery. 




Fig. 7. The picture stone from Sproge church was used during the Middle Ages as a piscina, i.e. as a drain for holy water. Photo: ATA.

used in secular buildings seems to point to a functional interpretation. There is, however, good reason to believe that the use of picture stones in church buildings had a more profound meaning. Such a meaning can be found in the tension between the pagan stones and the Christian church.

In this context it may be relevant to consider Adam of Bremen's information on Archbishop Unwan in Hamburg-Bremen, who was active in the beginning of the eleventh century (A.D. 1013-1029). He is said to have ordered the total annihilation of all pagan customs. He had the sacred groves felled and of the wood from them he had the churches renewed (Adam av Bremen 1984:96).

In the book Masse und Macht Elias Canetti has discussed destruction as a phenomenon. To destroy pictures that depict something is, according to Canetti, to destroy an order that is no longer accepted. The rigour by which these pictures have been maintained has been an expression of their perpetuity. The pictures have been there for a long time; one could almost get the impression that they have always been there, and that it was impossible to approach them with hostile intents. But, as a matter of fact, they can be thrown down and broken into fragments (Canetti 1985:16). The demolishing of statues representing overthrown rulers is a well-known historical example of such a symbolic outburst.

Adam of Bremen's information and Canetti's discussion give us a possible background to why pagan picture stones were demolished and used as building material in Christian churches. This could have been a way for the new faith to gain strength from the pagan past. The fact that the picture stones let themselves be inserted into this new context was apparently evidence of the superiority of the new faith. As a paradox, the presence of picture stones in the churches also expresses a kind of continuity between the old and the new.

Also the placing of the picture stones within the churches indicates that their use in the church building had a symbolic dimension. Many picture stones have been well visible at central positions. For example, several stones have been placed next to the altar with the pictorial side facing upwards. There the picture stones have been worn by the feet and knees of the priests for centuries (Nylén \& Lamm 1988:48-49). Other picture stones have had, if possible, even more spectacular positions. A picture stone from Sproge church (Lamm 224) has functioned as a piscina, that is, as a drain for holy water, fig. 7.

At least four picture stones (Lamm 2, 73, $168 \& 442$ ) have been used as foundations for baptismal fonts. One of these is a stone from Alskog church (Lamm 2), fig. 8. There the reshaped and pierced stone has been lying under the baptismal font with the pic- 




Fig. 8. After being reshaped and pierced, the picture stone from Alskog church was re-used as a foundation for the baptismal font. Photo: ATA.

torial side facing upwards. A sufficiently large part of the stone has been visible outside the font's base to make the pictures visible to the churchgoers (Lindqvist 1964:87). When the parish priest, through the christening, admitted new members into the congregation, he was literally standing on pagan ground, that is, on the picture stone.

The medieval baptismal fonts often show a contrast between the pictures on the upper and the lower half. The twelfth-century font from Alskog church that stood on the abovediscussed picture stone is an example of this, fig. 9. On the upper part sacred scenes from the Bible are depicted, while the lower part shows diabolic faces (Lindqvist 1964:87-88, cf. Roosval 1918). As a foundation for the font, the pagan picture stone can have strengthened this contrast.

It can be noted that some picture stones have secondary polishing grooves. In some cases these seem to relate to the building of the church (e.g. Lamm 215, cf. Lindqvist 1962). Maybe the tools used to build the Christian church were sharpened with the aid of pagan picture stones?

The large number of picture stones found in churches and the ways in which the stones have been used within the churches clearly indicate that the stones were ascribed deeper meanings than that of building material. Picture stones from a pagan past were obviously ascribed new meanings in the medieval Christian church.

\section{LOCAL LEGENDS}

The vast majority of picture stones have been found in later prehistoric graves and in medieval churches. Today only about 15 picture stones still stand at the place where 


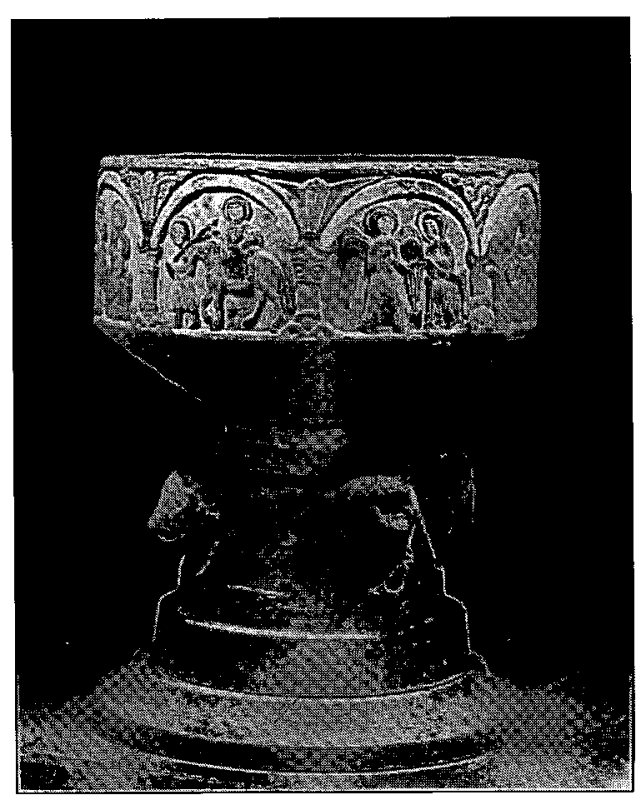

Fig. 9. The twelfth-century font from Alskog church stood on the picture stone in fig. 8. The picture stone can have strengthened the contrast between the font's upper and lower part.

Photo: ATA.

they were originally raised (Nylén \& Lamm 1988:170). During the last centuries only a small number of picture stones have been standing out in the open. Round these stones, however, there are a number of legends and stories. The picture stones have attracted attention and been ascribed meaning by the local peasantry. These interpretations have made the picture stones meaningful elements of the landscape.

The figures on the picture stones standing in the landscape have in most cases disappeared due to erosion. It is therefore the stones themselves that have attracted attention. Especially the shape of the stones has attracted attention; it is often said to resemble a human. Written documentation of legends and stories about the picture stones dates mainly from the nineteenth century, but many legends are probably much older. The legends usually deal with the reasons behind the raising of the stones. The explanation that is given always concerns a single incident that is said to have taken place at the spot where the stone is raised. The stones have also been given names that refer to these incidents.

Two picture stones (Lamm 35 \& 36) raised next to each other in Bro parish are named "The Stoneshrews of Bro" (Sw. "Bro Stainkällingar"), fig. 10. The legend tells of two raised stones with human shape. It is told that two shrews who were on their way to church one Christmas morning began to quarrel. They forgot about the peace of the holy day and cursed each other. They were then turned to stone, and as such they will stand till Judgement Day.

A similiar legend, which probably refers to some fallen picture stones, is known from the seventeenth century (cf. Ståhle 1969: 312-313).

In Buttle parish, in the middle of Gotland, there are two large picture stones (Lamm 43 \& 44) that are called "In the Middle of the Country" (Sw. "Midt på Landet"), fig. 11. According to the records, these stones too are said to be cut in a kind of human shape. They stand close together but are of different height. There are several stories about these stones. One story tells that the stones mark the place where a bride was killed during her bridal ride. Another story tells that two priests who were horse racing about a benefice fell down with their horses at this place. Usually, however, a different story is told. This is about two land surveyors who made a bet as to which of them could most accurately measure the middle point of Gotland. The stones are said to show how close their measurements came to each other, and the stones are therefore called "In the Middle of the Country." Finally, however, it was decided that it is the higher stone that really marks the middle.

In Fröjel parish there is a picture stone 


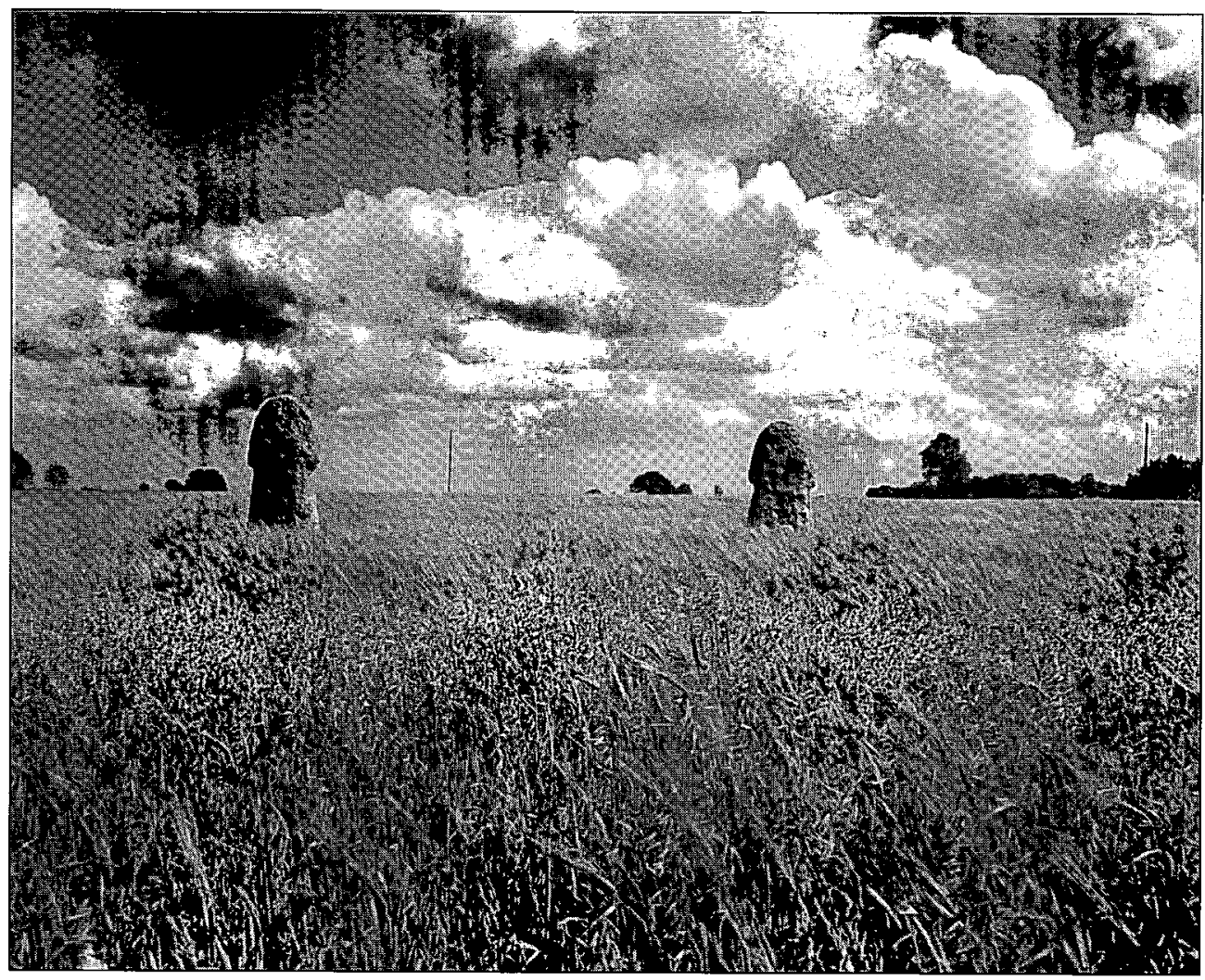

Fig. 10. A legend tells that the two human-shaped picture stones in Bro ("The Stoneshrews of Bro") are two shrews that were turned to stone. Photo: Pall-Nils Nilsson.

(Lamm 61) called "The High Stone" (Sw. "Höje-stenen") or "The Lord Stone" (Sw. "Herr-sten"), fig. 12. According to one legend, this stone was raised in memory of a noble officer who was killed during a battle with the Danes. This is supposed to have happened in 1361 when the Danish king Valdemar landed on the island. Another story tells that the stone was raised in memory of a bride who rode herself to death during her bridal ride. It is also told that people have tried several times to build a fence in front of the stone, but the fence has always been pulled down the following night. If the stone is fenced or pulled down, the people in the nearby farm are said to have no more peace.
It is also said that a large gold chain is hidden under the stone. Several treasure hunters have sought it in vain. It can also be noted that the stone stands on the borderline between two parishes. It has thus been used as a boundary marker.

Many legends and stories have been told about the picture stones by the peasantry during the centuries. The stories tell us quite a lot about the storytellers and the world in which they were living. The picture stones functioned as a kind of warning example in the landscape; they showed what could happen if you did not respect the prevailing order. If you acted in an ungodly way you could turn to stone or fall down dead. In this 




Fig. 11. Many legends are told about the two large picture stones in Buttle parish. One of the legends has given rise to the name of the stones: "In the Middle of the Country". Photo: ATA.

way the picture stones promoted the maintenance of the prevailing order.

The picture stones were, however, also used in very concrete ways. They were, for example, used in house foundations and as steps. Today this use is considered disrespectful. Instead the picture stones are valued as a cultural heritage from earlier generations of Gotlanders.

\section{GOTLANDIC IDENTITY}

The Gotlandic identity is very strong indeed. Both the islanders themselves and outsiders think that there exists something genuinely Gotlandic that separates the island and its inhabitants from the rest of Sweden. The tourist advertisement to attract other Swedes emphasizes that Gotland is another country (Sw. "Gotland, ett annat land"). On Gotland the distinction between Gotlandic and mainlandic is used very frequently (cf. Salomonsson 1988:172). A central part of the Gotlandic identity is the view of Gotland's history.

The Gotlandic view of the island's history was developed during the second half of the nineteenth century. It grew from a dissatisfaction with the insignificant role the island was considered to have been given within Swedish history. It was declared that the Gotlanders must be given a history to be proud of (Säve 1858). The Gotlanders felt that the Swedish government authorities had not shown any interest in the island for a long time. When the Swedish king Oscar II visited the island in 1891, it was the first visit by a Swedish ruler for more than two hundred and fifty years. This stepmotherly treatment from the Swedish mainland promoted the need to create a great Gotlandic 


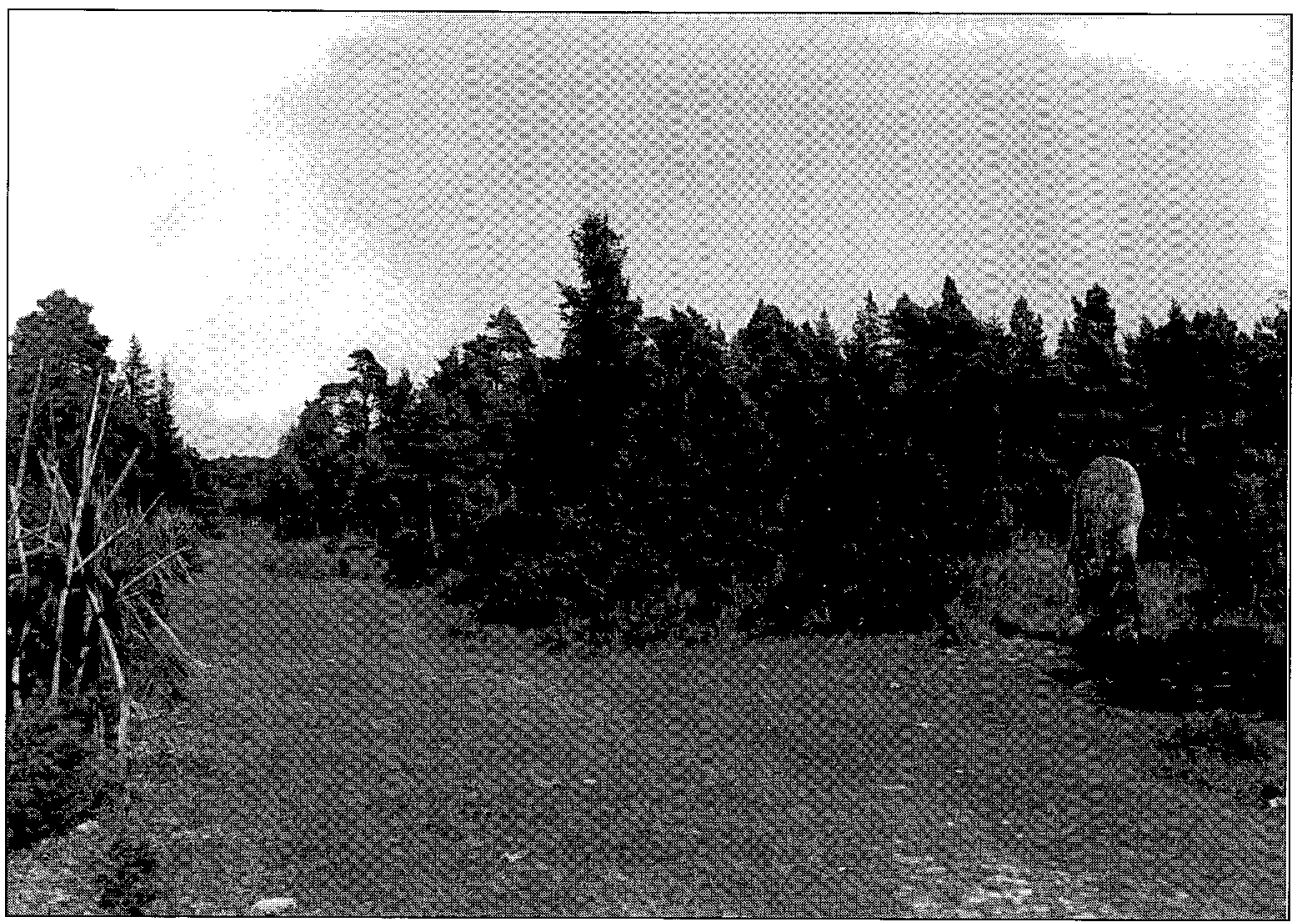

Fig. 12. "The High Stone" or "The Lord Stone" in Fröjel parish is raised next to an old road. There it has been observed and ascribed meanings by the passers-by through the centuries. Photo: ATA.

past, a past for the islanders to be proud of in the present (cf. Rönnby 1995:21-22).

In the Gotlandic history written during the late nineteenth century the island is said to have been inhabited by freedom-loving Gotlanders since time immemorial. These have resolutely refused all foreign demands for supremacy over the island. Gotland is said to have been an independent republic of peasants during the Viking Age and the early Middle Ages. The power is said to have been shared equally among the free farmers of the island (Snöbohm 1871). This view of the Gotlandic past still exists among many Gotlanders (cf. Salomonsson 1988). Today the archaeological views of Viking Age Gotland are strongly divided. On the one side there is the view of a self-governed, egalitarian republic of peasants (e.g. Östergren 1989). On the other side there is the view of a highly stratified society under foreign domination (e.g. Hyenstrand 1989). The differences in opinion coincide surprisingly well with whether the archaeologist originates from Gotland or not.

During the last couple of years a strongly chauvinistic writing of Gotlandic history has appeared (Gannholm 1990). According to this, Gotland has been the cultural centre in the Baltic region for several thousands of years. The motive for this new writing of Gotland's history is once again said to be that the island has been neglected in the official Swedish history. In this alternative Gotlandic history the picture stones are seen as evidence of a sophisticated Gotlandic culture. The picture stones are used to create an image of a historically founded Gotlandic identity.

One expression of the need for an own, 


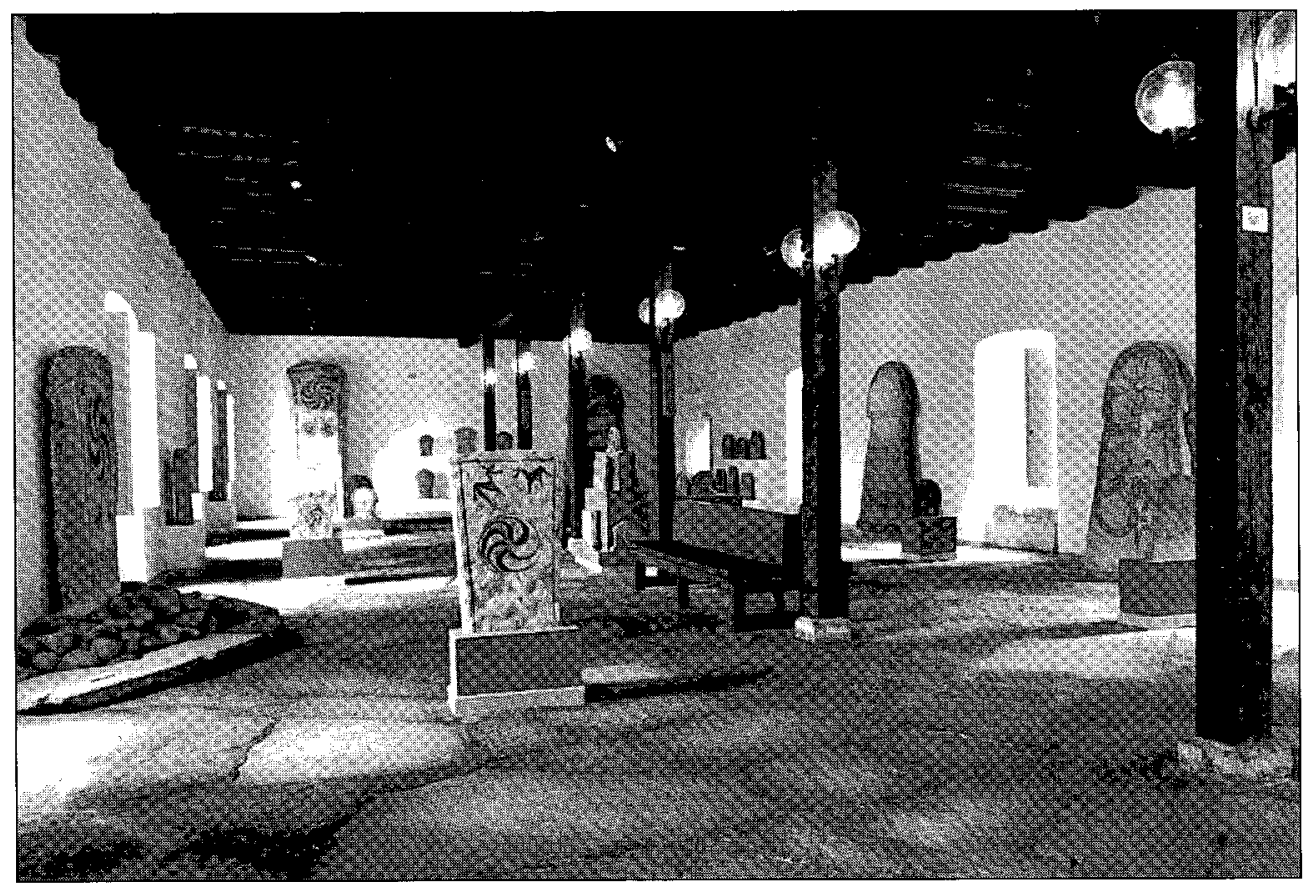

Fig. 13. The picture stone gallery in Gotland's Historical Museum strongly resembles a church hall. Photo: Gotland's Historical Museum.

Gotlandic history during the late nineteenth century is the establishing of Gotland's Historical Museum (Sw. Gotlands Fornsal) in 1879. The museum still exists, and as a provincial museum it focuses on Gotland's history and the distinctive archaeological character of the island. The picture stones form a central part of the museum.

The first room the visitor enters in the museum is in fact the picture stone gallery, fig. 13. It is a hall with thick, whitewashed walls, a lofty ceiling and stiff window recesses. The hall strongly resembles a church hall and calls for respect and silence. This impression is emphasized by the fact that many of the picture stones which have their resting place in the gallery today, have been collected from medieval churches where they were formerly walled in. The monumentality and sacred character of the picture stone gallery invites the visitor to admire and almost worship the stones and with them the Gotlandic past.

Also the symbol for Gotland's Historical Museum is taken from a picture stone (Lamm 153), fig. 14, left. The museum authorities on the mainland, however, have also made use of the Gotlandic picture stones. The symbol for the Museum of National Antiquities (Sw. Statens Historiska Museum) in Stockholm is also a rider (Lamm 4), fig. 14, right. The horse in the latter symbol has eight legs, however, and because of that it has been identified as Odin's steed, Sleipnir. Perhaps this should be seen as an expression of the central museum's closer ties to the gods?

Some picture stones have been objects of dispute between Gotlandic and mainlandic interests. Probably the most reproduced picture stone is a large stone from Hammars, in Lärbro parish (Lamm 184), fig. 15. It was discovered together with three other picture 


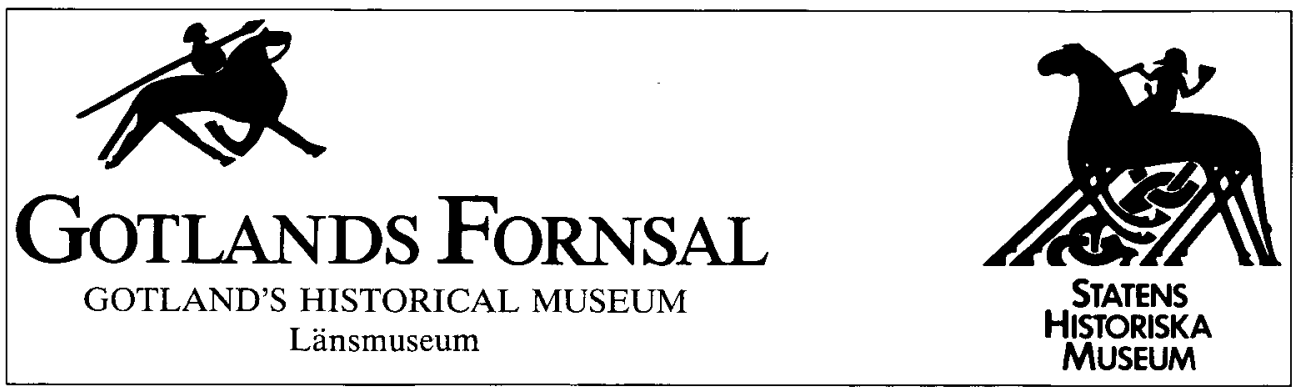

Fig. 14. Figures derived from Gotlandic picture stones are used as symbols for the museum authorities on the island as well as on the mainland.

stones in the beginning of the twentieth century. In 1923 there was a struggle about this stone, which is the largest and most figurerich of the four stones found at Hammars. The struggle was between the Museum of National Antiquities in Stockholm, which had decided to take care of the most "valuable" stone, and Gotlandic interests that wanted to keep the stone on the island.

The question of the future residence of this picture stone upset many Gotlanders and led to a lively discussion in the local press. The contributions to the debate had headings like, "Gotland is deprived of its picture stones" (Sw. "Gotland berövas sina bildstenar"), "Our ancestors' Gotland" (Sw. "Vara fäders Gotland"), "The Gotlandic heritage" (Sw. "Det gotländska arvet"), and "Will we be plundered of the last one?" (Sw. "Skola vi bli utplundrade pà den sista?").

The debate started with a short paragraph announcing that one of "our" most splendid picture stones was lying in the harbour of Slite, for export to Stockholm. The paragraph states that peasants are said to plunder "their" ancient graves, but the director-general of the Central Board of National Antiquities (Sw. Riksantikvarien) plunders "our" ancient graves in his own way (Gotlänningen 18.5.1923). The next day the question was asked if "we" Gotlanders should not go to the harbour of Slite and save the splendid picture stone for "our" island. All the other magnificient stones are said to already have

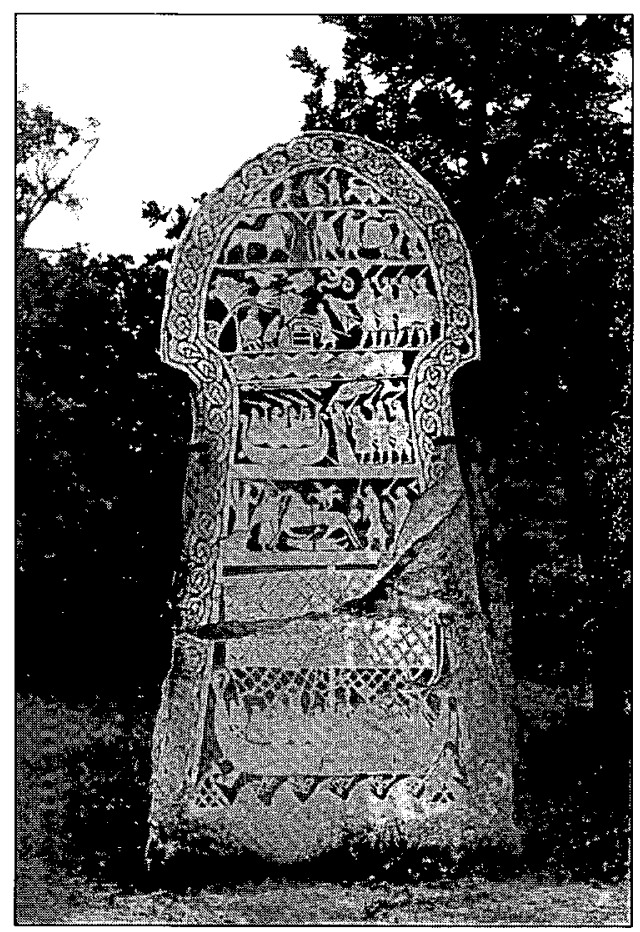

Fig. 15. In 1923 the picture stone from Hammars in Lärbro parish was the object of a dispute between Gotlandic and mainlandic interests. Should the stone be allowed to stay on the island or should it be "exported" to Stockholm? Photo: ATA. 


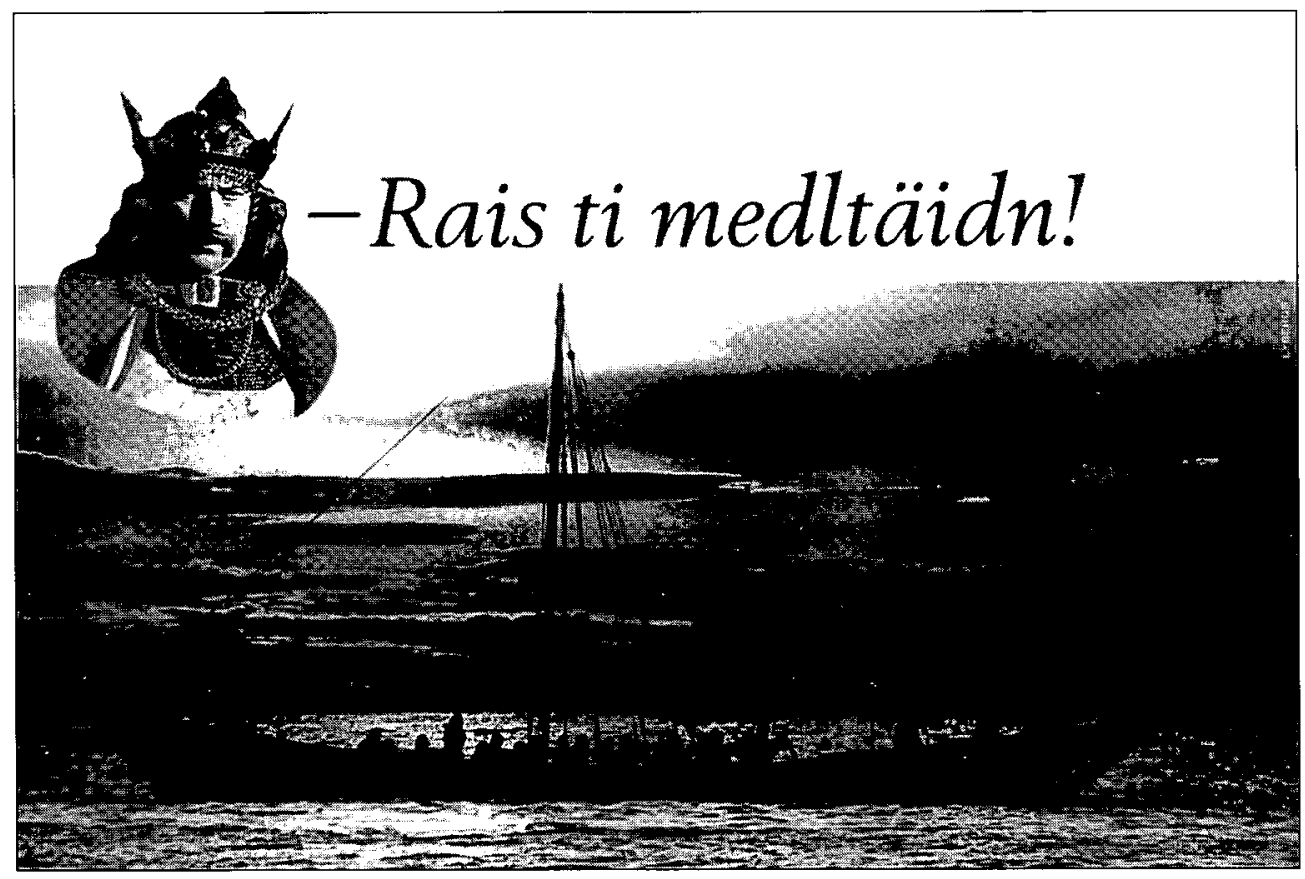

Fig. 16. "-Travel to the Middle Ages!" The Gotlandic tourist industry draws heavily on the island's historical heritage.

travelled the long and sad way over the sea to become disregarded numbers in the national collections. In the worst cases they have just ended up in the museum cellar. The debater complains that the province is being deprived of all its valuable ancient objects. He appeals to the director-general of the Central Board of National Antiquities to have compassion with the Gotlanders' emotions and let the stone stay on the island (Ekman 1923). Other debaters express similar viewpoints and stress that Gotland step by step is being impoverished of its cultural heritage (e.g. Wigsten 1923; Österberg 1923).

The newspaper debate and the public opinion impelled the county governor ( $\mathrm{Sw}$. landshövdingen) to send a telegram to the director-general of the Central Board of $\mathrm{Na}$ tional Antiquities. The county governor reports that the information that yet another picture stone shall be taken away from Gotland has caused a lot of sorrow and dis- couragement on the island. Therefore, he requests that the stone should be allowed to stay on Gotland for the present.

This request led to a new meeting in Stockholm. It was decided that the museum in Bunge on Gotland on certain conditions could have the stone as a deposition. These conditions were accepted and the stone was transported from the harbour in Slite and raised at the museum. There it still stands, and today the stone is a well-known tourist attraction.

Tourism is very important for Gotland. Next to agriculture, the tourist industry is the most important. The island has about 58,000 inhabitants and sees annually (1993) almost half a million tourists. In the marketing of Gotland the island's history is actively used. In the marketing - prehistory, the Viking Age and the Middle Ages tend to be mingled together. Gotland is described as an island where the past is always present. The large 


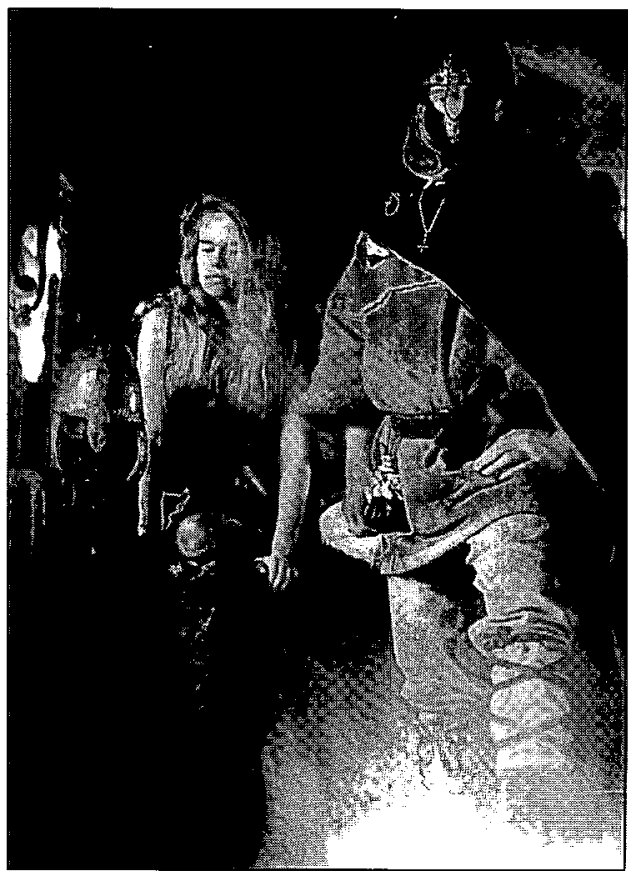

Fig. 17. All tourists on Gotland are invited to "an authentic Viking feast."

number of ancient monuments, ruins and medieval churches partly justifies this image.

In the advertisement you are, for example, exhorted to "-Travel to the Middle Ages!" (Sw. "Rais ti medltäidn!"), that is, "-Travel to Gotland", fig. 16. The advertisment shows a ship silhouette that is easily associated with the ships on the picture stones. When you arrive on Gotland you are invited to the "Viking village." It is said to be "a ninth-century Viking village, authentically reconstructed down to the smallest detail". You are also invited to "be a guest of Erik Bloodaxe at an authentic Viking feast." The enclosed picture certainly speaks for the authenticity, fig. 17.

The picture stones have thus been used to create an image of a Gotlandic identity that separates the island from mainland Sweden and the rest of the world. This sense of "otherness" has served to unite the Gotlan- ders as well as being a sales argument in the tourist industry.

\section{CONFIRMING AND CREATING A VIKING AGE IMAGE}

As we have seen, the Gotlandic picture stones are closely tied to the island. Of the more than 440 stones that are known today, only four have been discovered outside Gotland. None of these belong to the approximately 165 stones of the Viking Age type with many figures (group III in fig. 1).

In spite of this, the pictorial world found on these Viking Age stones has by far exceeded the Gotlandic borders and is today associated with the Scandinavian Viking Age as a whole. One example of this is the front cover of T.D. Kendrick's A History of the Vikings (1968), fig. 18. As the title states, this

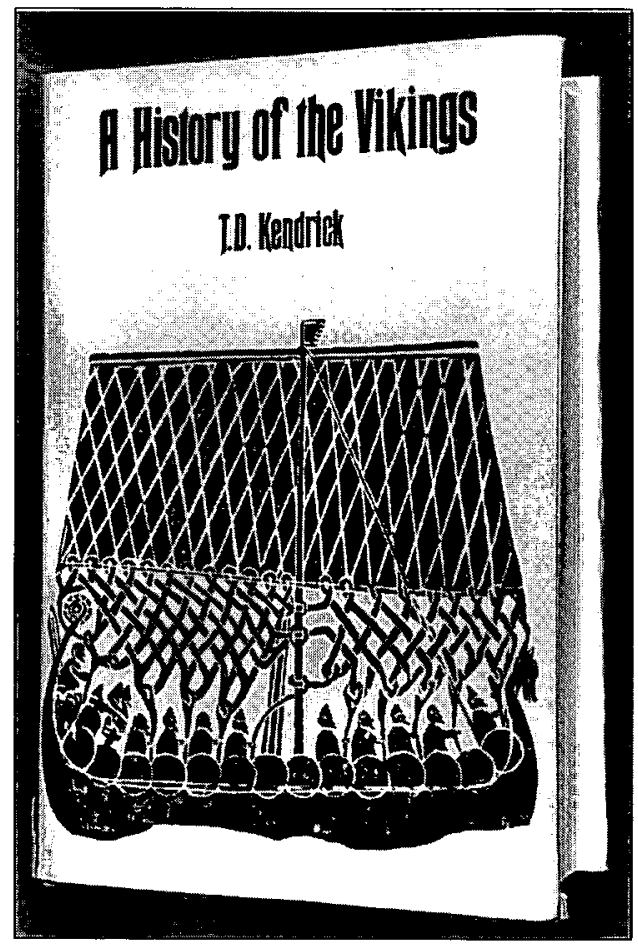

Fig. 18. Figures from the Gotlandic picture stones are frequently used to illustrate the Scandinavian Viking Age as a whole. 


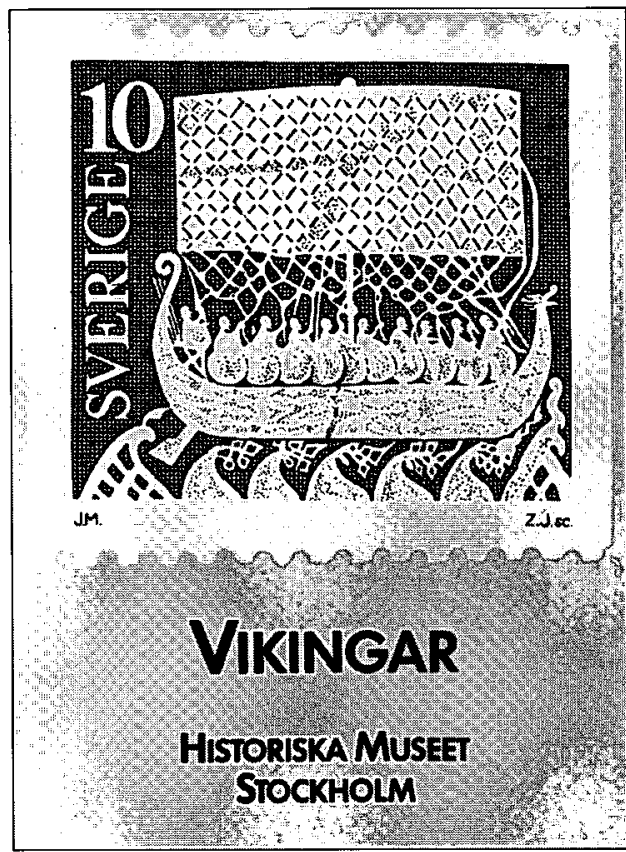

Fig. 19. The silhouette pictures of sailing-ships crewed with armed men that are found on the picture stones have become a metaphorical representation of the Viking Age.

is a book about the Viking Age in general, but the picture on the front cover is, of course, taken from a Gotlandic picture stone (Lamm 295). This is in no way unusual; on the contrary, figures from picture stones are used over and over to illustrate the Viking Age. And the most commonly used figures are the ships.

Another example of this is a postcard advertising the exhibition "Vikings" that took place at the Museum of National Antiquities in Stockholm in 1981, fig. 19. Here a stamp (issued in 1973) is used as a symbol, a stamp that shows a sailing-ship from a Gotlandic picture stone. What is more, the ship figure is actually taken from the picture stone that was the object of dispute in 1923 (see above).

The popularity of the picture stone sailing-ships as symbols of the Scandinavian Viking Age is surely related to the common opinion on what characterizes this period. Both archaeologists and the general public probably associate the Viking Age primarily with Viking raids, Viking ships and Vikings, that is, armed men. A look at the entry "Viking" in Encyclopadia Britannica (1964) seems to confirm this view. First, the word "Viking" is explained to correspond to the word "warrior." Then follows quite a long account divided into two subheadings: "The Viking Raids" and "The Viking Ships."

The silhouette pictures of sailing-ships crewed with armed men that are found on the picture stones do not only serve as illustrations; they have also become a metaphorical representation of a whole epoch. The ship figures actively confirm and recreate the image of the Viking Age as a period characterized by armed men and Viking ships. Spread to the general public, for example in the form of stamp motifs, the picture stone ships form the contemporary image of the Viking Age.

As the richest pictorial material from the Scandinavian Viking Age, the picture stones have had an enormous influence in forming our image of the Viking Age. Since the stones are from the same period they serve to illustrate, they are supposed to give true evidence. It has only rarely been discussed whether the stones depict everyday reality or something completely different (cf. Varenius 1992:52-54). An important reason for this lack of discussion is that many have had an interest in the image of a powerful and expansive past. This Viking Age image has been adopted by local sportsclubs as well as by the export industry (cf. e.g. Lundström 1972).

The Viking Age is the only period in Scandinavian prehistory that is generally known outside Scandinavia. Through the frequently reproduced ship figures, the Gotlandic picture stones have sailed into world history as symbols of the Viking Age. The monuments which in one context are symbols of the specifically Gotlandic, are thus 
in another context symbols of the whole of Scandinavia. Meaning obviously changes with context.

\section{CONCLUDING REMARKS}

The Gotlandic picture stones have been incorporated into a large number of contexts throughout history. Each of these would surely be worth a closer examination. In this text, however, I have presented a survey of different contexts, focusing on the multiplicity of meaning rather than each particular case.

The survey has shown that the meaning of the picture stones is obviously not restricted to the time when they came into being. Instead the picture stones have been recurrently interpreted and used. What consequences does this have for archaeology as a discipline?

I believe that a truly meaningful archaeology - that is, an archaeology full of meaning - must take into consideration the many contexts in which objects have been ascribed meaning. Thereby, archaeology will cross the borders of what is traditionally conside- red as other disciplines and the search for meaning will become a joint venture. In this way the archaeological interest in contexts will ultimately change the context of the discipline itself.

\section{English revised by Laura Wrang.}

\section{ACKNOWLEDGEMENTS}

This text was originally presented in November 1994 in the series of Garrod Lectures at the Department of Archaeology, University of Cambridge. It was the organizers of this lecture series, Dr. Marie Louise Stig Sørensen and Dr. Colin Shell, who suggested the Gotlandic picture stones as the topic for my lecture. I want to express my sincere thanks to them for inviting me and for focusing my interest on these stones.

\section{ABBREVIATIONS \\ ATA Antikvarisk-Topografiska Arkivet, Stockholm. (The Antiquarian-Topo- graphical Archive, Stockholm.)}

Lamm + No. Refers to the catalogue of the Gotlandic picture stones in Lamm 1988.

\section{REFERENCES}

Adam av Bremen. [1984]. Historien om Hamburgstiftet och dess biskopar. Proprius förlag. Stockholm.

Althin, A. 1967. Mölner i Väte - en preliminär redogörelse. Gotländskt Arkiv. pp. 39-42.

Andrén, A. 1993. Doors to other worlds: Scandinavian death rituals in Gotlandic perspectives. Journal of European Archaeology, Volume 1:1. pp. 33-56.

Bradley, R. 1993. Altering the Earth. The Origins of Monuments in Britain and Continental Europe. The Rhind Lectures 1991-92. Society of Antiquaries of Scotland. Monograph Series Number 8. Edinburgh.

Burström, M. 1993. Mångtydiga fornlämningar. En studie av innebörder som tillskrivits fasta fornlämningar $i$ Österrekarne härad, Södermanland. Stockholm Archaeological Reports,
Nr. 27. Stockholm.

Canetti, E. 1985. Massa och makt. (Sw. translation of Masse und Macht [1960])

Chippindale, C. 1983. Stonehenge Complete. Thames and Hudson. London.

Ekman, C. E. 1923. Våra fäders Gotland. Gotlänningen 19.5.1923. and also Gotlands Allehanda 19.5.1923. (Daily papers)

Encyclopedia Britannica, Volume 23. 1964.

Gannholm, T. 1990. Gutarnas historia. Frain förhistorisk tid till den slutliga svenska annekteringen 1679. Stånga.

Gotlänningen. 18.5.1923. (Daily paper)

Hyenstrand, Å. 1989. Socknar och stenstugor. Om det tidiga Gotland. Stockholm Archaeological Reports, Nr 22.

Kendrick, T. D. 1968. A History of the Vikings. Second edition. London. 
Lamm, J. P. 1988. Catalogue. In: Nylén, E. \& Lamm, J. P. 1988. (see below) pp. 177-200.

Lindow, J. 1993. Sailing and Interpreting the Ships on the Gotland Stones. The American Neptune 53. pp. 39-50.

Lindqvist, S. 1941-1942. Gotlands Bildsteine I-II. Kungl. Vitterhets Historie och Antikvitets Akademien. Stockholm.

- 1945. Bildstenarna. In: Boken om Gotland.pp. 108-124.

- 1962. Jättestenen frăn Sanda och andra nyfunna bildstenar. Gotländskt Arkiv. pp. 7-22.

- 1964. Forngutniska altaren och därtill knutna studier. In: Kungl. Humanistiska VetenskapsSamfundet i Uppsala, Arsbok 1960-1962. pp. 1-185. Almqvist \& Wiksell. Uppsala.

Lundström, I. (Ed) 1972. Viking. Forntidsdrömoch verklighet. Utställningskatalog. Statens Historiska Museum. Stockholm.

Måhl, K. G. 1990. Bildstenar och stavgardar - till frågan om de gotländska bildstenarnas placering. Gotländskt Arkiv. pp. 13-28.

Nylén, E. 1966. Gotländska fornminnen. Svenska Turistföreningens Årsskrift 1966. pp. 183-204. Stockholm.

Nylén, E. \& Lamm, J. P. 1988. Stones, Ships and Symbols. The Picture Stones of Gotland from the Viking Age and Before. Gidlunds. Stockholm.

Roosval, J. 1918. Die Steinmeister Gottlands. Eine Geschichte der führenden Taufsteinwekstätte des schwedischen Mittelalters: ihrer Voraussetzungen und Begleit-Erscheinungen. Stockholm.

Rönnby, J. 1995. Bålverket. Om samhällsförändring och motstånd med utgångspunkt från det tidigmedeltida Bulverket $i$ Tingstäde träsk på Gotland. Studier från UV Stockholm, Nr 10. Riksantikvarieämbetet. Stockholm. Diss.

Salomonsson, A. 1988. Perspektiv på det folkegna
- om gotländsk mentalitet $\mathrm{i}$ äldre och nyare tryck. Gotländskt Arkiv. pp 171-178.

Snöbohm, A. Th. 1871. Gotlands land och folk. Örebro.

Stenberger, M. 1962. Das Gräberfeld bei Ihre im Kirchspiel Hellvi auf Gotland. Der Wikingerzeitliche Abschnitt. Acta Archaeologica, Vol. XXXII, 1961. pp. 1-134. Kopenhagen.

Ståhle, C. I. (Ed) 1969. Rannsakningar efter antikviteter: Band II. Häfte I. Kungl. Vitterhets Historie och Antikvitets Akademien. Stockholm.

Swanström, E. 1983. En bildsten från S:t Hans ruin. Gotländskt Arkiv. pp. 55-58.

Säve, C. 1845. Tjängvide-stenen på Gotland. Runa, antiquarisk tidskrift. Ed. R. Dybeck. pp. 82-93. Stockholm.

- 1858. Gotländska minnen. In: Gotländska skrifter I. 1978. Jönköping.

Varenius, B. 1992. Det nordiska skeppet. Teknologi och samhällsstrategi $i$ vikingatid och medeltid. Stockholm Studies in Archaeology 10. Diss.

Wigsten, H. 1923. Skola vi bli utplundrade på den sista? Gotlands Allehanda 29.5.1923. (Daily paper)

Österberg, K. P. A. 1923. Det gutniska arvet. Gotlands Allehanda 22.5.1923. (Daily paper)

Östergren, M. 1989. Mellan stengrund och stenhus. Gotlands vikingatida silverskatter som boplatsindikation. Theses and Papers in Archaeology 2. Stockholm University. Diss.

Unpublished sources

Antikvarisk-TopografiskaArkivet, Stockholm. (The Antiquarian-Topographical Archive, Stockholm.)

Nordiska museets folkminnessamling, Stockholm. (The Folklore Collections of the Nordic Museum, Stockholm.) 